\title{
The Influence of Kegel Exercise on Urine Incontinension Reduction in Elderly
}

\author{
Tien Hartini, Endang Banon Sri Bharaty ${ }^{*}$, and Titi Sulastri \\ Department of Nursing, Health Polytechnic, Ministry of Health Jakarta III \\ Jalan Arteri JORR Jatiwarna Pondok Melati Bekasi Indonesia \\ *Corresponding author's email: endangbanon [AT] yahoo.com
}

\begin{abstract}
The elderly is a period of time when various health problems influence their lives, in general, the elderly complaint about various kinds of symptoms that are felt due to the condition of body organs that have a setback. One of the health problems often suffered by the elderly is urinary incontinence. This needs a special attention along with the increasing elderly population in Indonesia. Urinary incontinence is the process of uncontrolled urinary discharge at an undesirable time regardless of frequency and amount, due to weak pelvic floor contraction which will cause social and hygienic problems of the sufferer. Kegel Exercise or Kegel Exercise is a gymnastic activity that aims to strengthen the pelvic floor muscles, especially the pubococcygeal muscles so that a woman can strengthen the urinary tract muscles and can cure the inability to hold urine urination/incontinence. The purpose of this study was to determine the effect of kegel training on decreasing urinary incontinence in the elderly lived in nursing home. This is a quasi-experiment research with the Pretest-Postest One Group approach. The population of this study were all elderly at Tresna Werdha Budi Mulia Nursing Home Ciracas in East Jakarta who had urinary incontinence. 23 samples were taken in nonrandom. Data were gathered using an observation instrument by conducting active observations and filling out the checklist about 24-hour urination filled directly by the elderly every day during the study. Data analysis used non-parametric statistics with Paired T-test or Wilcoxon Signed Rank Test. The results of the T-dependent test, it was found that $P$-value was $0,000(p<0.05)$ which showed that there was an effect of kegel training on the frequency of urinary incontinence There is a significant difference between urinary incontinence before exercise and urinary incontinence as a Kegel exercise. The results of this study are expected to contribute, both for the elderly who live in nursing homes and for health service institutions and educational institutions as well as for the development of nursing science in providing nursing care for elderly who experience urinary incontinence.
\end{abstract}

Keywords— Kegel Exercise, Urinary Incontinence, Elderly, Nursing Home

\section{INTRODUCTION}

The ageing process will usually be covered physically-biologically, and psychosocially. Physical changes are decreased, decreased nervous system, auditory system, visual system, cardiovascular system, respiration, endocrine system, skin system, urinary system, musculoskeletal system [1]. Changes that occur in the urinary system is a decrease in vaginal muscle tone and urinary tract muscle (urethra) becomes weak caused by a decrease in estrogen hormone, causing urinary incontinence, capacity up to $200 \mathrm{ml}$ or increase the frequency of urination. Urinary incontinence is a health problem that is often found in the elderly, especially women. Urinary incontinence is an uncontrolled elimination of urine from the bladder or occurs outside of desire. Elderly or family rarely complain about the problems of urinary incontinence they experience, and others because that embarrassing or taboo problems to tell and also because the condition is something that is normal for the elderly and does not need to be treated. It was reported that more than half of elderly nursing residents suffer from urinary incontinence [2].

Kegel exercises are the pelvic or gymnastics train which aims to strengthen the pelvic muscles, especially the pubococcygeal muscles so that a woman can strengthen the urinary tract muscles. Kegel exercises can also cure the inability to hold urine (urinary incontinence) [3].

The higher rate of urinary incontinence and the resulting impact requires the support of all parties, especially family and society as a support system for sufferers. Institutional management support that is carried out in synergy with community participation can produce new intervention strategies for continuity of nursing and reduce health problems experienced by the elderly. One of the interventions that can be carried out is the Kegel Exercise activity with elderly gymnastics activities in elderly training activities at the Home. 
Elderly at the Nursing Home has never been trained to do Kegel training with the aim of reducing the rate of urinary inconvenience, as well as for related research that has never been done. Based on the above background, we are interested in conducting research on the effect of Kegel Exercise on decreasing urinary incontinence in the elderly at Tresna Werdha Budhi Mulia Nursing Home Ciracas, East Jakarta. The results of this study are expected to contribute, both for the elderly who live in nursing homes and for health service institutions and educational institutions as well as for the development of nursing science in providing nursing care for elderly who experience urinary incontinence.

\section{METHODS}

This research is a quasi-experimental study with One Group Pretest-Postest approach to see the possibility of a causeand-effect relationship that appears after being given Kegel exercises with a decrease in the frequency of incontinence. This design uses two measurements, namely before and after treatment. The study sample determined 40 respondents from 190 elderly people at Tresna Werdha Budhi Mulia Nursing Home Ciracas East Jakarta, but after being identified based on inclusion and exclusion criteria, there were 26 elderly people who met the criteria and after informed consent was made, only 23 elderly people were willing to become respondents. For that research subject taken in the total sample. The data collection process is carried out in August - September 2017. The data collection procedure begins with training instructors and investigators who will assist in the process of data collection. Disseminating research instruments to the elderly or accompanying, then pre-intervention the respondent by observing urinary incontinence for 3 days, then calculating the average incidence of the disease, followed by interventions namely Kegel Exercise guidance as much as twice a week for 1 month (8 exercises). Among the guided exercises, respondents were asked to exercise independently two times a day and respondents wrote the incident of micturition or gave a checklist on the monitoring sheet for urination, under the supervision of the investigator. After training for 1 month, investigators monitored the decrease in urinary incontinence in respondents for 3 days through interviews and observations, then calculated the average incidence of micturition.

\section{RESULTS}

Respondents who participated in Kegel exercises were the majority of women (58.5\%), with age above 65 years (75\%) had lived at Nursing Home 5 years or less $(69.6 \%)$, with a history of average urinary incontinence $1-2$ year $(65.2 \%)$.

There is an increase in the number of respondents with normal mating frequencies, from $60.9 \%$ to $87.0 \%$. or there is a decrease in the number of respondents whose frequency of entry exceeds normal, between $34.8 \%$ to $13.0 \%$. The average frequency of micturition before Kegel exercises was 7 times, with a standard deviation of 2.234, and the average frequency of micturition after exercise was 5 times with a standard deviation of 1.584.

The average frequency of micturition on calculations before exercise was 7 times, with a standard deviation of 2.234. In the calculation after the Kegel exercise intervention was obtained the average frequency of micturition was 5 times with a standard deviation of 1.584 . The difference in mean value between before and after measurements is 1.565 with a standard deviation of 1.326 . From the results of the paired t-test, it was found that the value of $\mathrm{P}<0.001(\mathrm{P} . \mathrm{value}<0.05)$.

\section{DISCUSSIONS}

1. Characteristics of Respondents

All respondents stated that they regularly attend physical training. The results of the study most of the respondents were women. This is in accordance with the results of the 2012 Indonesian Statistics Agency Susenas which shows that female gender is more than men [4].

The average age of respondents is 65 years and above. Increasing age will have an impact on the deterioration of functions both physiologically and psychologically and socially [5]. As a result of increasing age, the elderly will experience changes that indirectly demand the elderly to adapt continuously to the changes that occur. Changes that occur in the elderly include changes in physical conditions, changes in mental conditions, and psychosocial changes. Changes in the physical condition of the elderly include changes from the cellular level to all organs of the body; including the neuromuscular system, and the urogenital system. These changes can occur physiologically or pathologically. Physiologically, changes in the elderly urogenital system include changes in kidney function that are increasingly less efficient in removing metabolic waste residues from the blood, in elderly people aged 65 years will experience a decrease in urinary incontinence which can be caused by a variety of health problems, such as obesity, constipation, and chronic cough [6].

Physiological changes that occur in the elderly include changes in the urogenital system, namely: decreased vaginal muscle tone and urinary tract door muscles (urethra) caused by a decrease in estrogen hormones, causing urinary incontinence, muscle muscles become weak, capacity decreases to $200 \mathrm{ml}$ or causes frequency of urination increases [7]. 
Changes in the urogenital system result in increased urinary incontinence and stress due to decreased perineal muscle tone. The function of the affected sphincter causes the bladder to leak when coughing or sneezing. Disturbed brain function can lead to bladder contractions, there is an obstacle to urinary discharge with bladder dilation, a lot of urine in the bladder to excessive capacity. It was reported that more than half of elderly nursing residents suffer from urinary incontinence [2,7].

2. Average Picture of Frequency of Elderly Urine Incontinence / Incontinence Before and after Kegel Exercise Intervention

The result of this study shows a condition similar to the results of Ananingsih's research [8], namely the frequency of elderly voiding at the Tresna Werdha Teratai Social Institution in Palembang before and after Kegel exercises, with a median value of urine incontinence before Kegel exercises 5 times and the frequency of the elderly often urinating 7 times. While the median value of urinary incontinence after Kegel exercises 4 times and the frequency of the elderly often urinate 6 times.

3. Overview of the Effect of Kegel Exercise Interventions on Decreasing Frequency of Urinary Incontinence in the Elderly

This study can be concluded that there is a significant difference between the frequency of micturition before exercise and the frequency of micturition as a Kegel exercise, which means it can be said that Kegel Exercise has a significant effect on decreasing urinary incontinence.

This result is supported by other research in the Palembang Nursing Home for the Elderly Nursing Home, the results of statistical tests using the Wilcoxon statistical test, obtained p-value $=0.001$, this showed that there was an effect of kegel training on decreasing elderly urinary incontinence [9]. Another study showed that after doing kegel exercise there was a decrease in the frequency of urine incontinence by $21.6 \%$ from 10,043 times to 7,871 times [10]. From the results of the T-dependent test, it was found that P-value was 0,000 which showed that there was an effect of Kegel training on the frequency of urinary incontinence in the elderly at Pucang Gading Semarang Nursing Home. Nursalam states that Kegel exercises are physical activities arranged in a program that is carried out repeatedly to improve body fitness. Kegel exercises are very useful for strengthening the skeletal muscles on the pelvic, thus strengthening the external sphincter function of the bladder [11].

Pelvic floor muscle training was introduced by an obstetrician named Kegel in 1940 that Kegel exercises are very useful for strengthening skeletal muscles on the pelvic floor for postpartum, thus strengthening the external sphincter function of the bladder. This exercise continues to be developed and subsequently carried out on the elderly who experience stress incontinence problems namely uncontrolled urine expenditure due to sneezing, coughing, laughing or doing physical exercise and urgency incontinence. Kegel exercises can improve the function of the pelvic floor muscles, which is a series of muscles from the pelvic bone to the tailbone.

A study of the elderly at the Sindang Asih Nursing Home Semarang in 2009. Kegel Exercise which was conducted 10 times in 3 weeks caused a decrease in the frequency of urinary incontinence by $18.3 \%$ from 9.86 times to 6.19 times [12]. This study modified Kegel exercises on the elderly at the Tresna Werda Budi Mulia Nursing Home Ciracas East Jakarta, every day at least twice for 4 weeks, with instructor guidance and facilitator monitoring twice a week This was done based on the condition of the Elderly that the ageing process (ageing process) is a natural process accompanied by a decline in physical, psychological, and social conditions, which in terms of pre-psychological and social conditions in the elderly allow senility or forget new things. For that reason, Kegel exercise in the elderly needs to be done regularly in a relatively long time and inconsistent monitoring so that the elderly keep doing Kegel exercises regularly.

\section{CONCLUSIONS}

Characteristics of the elderly who were respondents who participated in the Kegel exercises were the majority of women with age above 65 years, the education level of the most respondents was junior secondary education and below. Have lived at Nursing Home 5 years or less with a history of urinary incontinence on average 1-2 years.

There is an increase in the number of respondents with normal mating frequencies or there is a decrease in the number of respondents whose frequencies exceed normal. The average frequency of micturition before Kegel exercises is 7 times, and the average frequency of micturition after exercise is 5 times.

There is a significant difference between urinary incontinence before exercise and urinary incontinence as a Kegel exercise, which means it can be said that Kegel Exercise has a significant effect on decreasing urinary incontinence.

Kegel exercises can be effective in reducing the frequency of urinary incontinence in the elderly if done routinely and continuously under guidance and monitoring.

Researchers hope, the results of this study will be applied for the manager of the institution, especially nurses to better introduce and teach, and then conduct monitoring by always reminding the elderly to do Kegel exercises regularly, both in the elderly who have incontinence or not. 


\section{ACKNOWLEDGEMENT}

This study has been approved ethical clearance from Health Polytechnics Ministry of health Jakarta III ethics committee. Thanks to Director of Health Polytechnics Ministry of health Jakarta III for funding this research, Head of Tresna Werdha Budhi Mulia Home Nursing Ciracas East Jakarta for research location

\section{REFERENCES}

[1] Nugroho, Wahyudi. Gerontik \& Geriatrik, Jakarta: EGC. 2008.

[2] Brunner\&Suddarth. Buku Ajar Keperawatan Medikal Bedah. EGC, Jakarta. 2011.

[3] Widianti, A. Proverawati. Senam Kesehatan. Yogyakarta: Nuha Medika. 2010.

[4] Kementerian Kesehatan Indonesia Republik Indonesia. Profil Kesehatan Indonesia 2012. Jakarta: Kementerian Kesehatan Republik Indonesia. 2014.

[5] Smeltzer, C. Suzanne. Buku Ajar Keperawatan Medikal Bedah Ed. 8 Volume 2. Jakarta: EGC. 2001.

[6] Padila. Buku Ajar Keperawatan Gerontik. Jakarta: EGC. 2013.

[7] Potter, P.A, \& Perry, A.G. Buku Ajar Fundamental Keperawatan: Konsep, Proses, dan Praktik. (Edisi 4). Alih Bahasa: Yasmin Asih, dkk. Jakarta: Penerbit EGC. 2009.

[8] Ananingsih, A., Ristriana, Suhairy, Pengaruh Latihan Kegel Terhadap Perubahan Inkontinensia pada Lansia di PSTW Teratai Palembang. 2013.

[9] Pudjiastuti Fisioterapi pada Lansia. Jakarta: EGC. 2003.

[10] Widyaningsih. Pengaruh latihan Kegel Terhadap Frekuensi lnkontinensia Urine Pada Lansia di Panti Wreda Pucang Gading Semarang. Dibuka tanggal 12 Februari 2017 dari http://repository.unimus.ac.id/2009/pengaruh latihan kegel terhadap frekuensi inkontinensia urin pada lansia. 2009.

[11] Nursalam. Asuhan Keperawatan pada Pasien dengan Gangguan Sistem Perkemihan. Jakarta: Salemba Medika. 2007.

[12] Hidayati, Puji. Pengaruh Latihan Kegel terhadap Frekuensi Inkontinensia Urin pada Lanjut Usia di Panti Werda Rindang Asih II Semarang, 2009. 